\title{
The Expression of Justice in China
}

\author{
Flora Sapio, Susan Trevaskes, Sarah Biddulph, Elisa Nesossi
}

Claims about a strident pursuit of justice weave through all of China's modern history. Intellectual, political and social ferment that exploded on to China's political stage on 4 May 1919 was motivated by a common will among the intellectual and political class to find a proper place for China among the family of nations. Pursuit of justice underpinned this movement, as it did the establishment of the Republic of China (ROC) eight years earlier. Communism was cultivated in China in the 1920s replete with a political vocabulary that was indebted to liberal and democratic political philosophies as much as it was to communist ideology. Here too, it was the ideal of attaining justice for the populace that prompted popular reaction to the inequalities, corruption and violence endemic in the ROC from the 1920s to the 1940s. This quest drove the civil war and the foundation of the People's Republic of China (PRC) in 1949. Over the course of the revolutionary era in the 1930s and 1940s, ideas put forward by some leading theorists and activists of the Chinese Communist Party advocating for a more democratic-liberal socialism were suppressed and eventually wiped out, while Maoist discourse became progressively privileged.

The launch of successive waves of ideological reform during the years before establishment of the PRC obeyed a certain political logic that forced some notions of justice out of the political picture while privileging others. And after the PRC's establishment in 1949, efforts to achieve what Party leaders articulated as a just society drove the mass campaigns that were launched in the 1950s and 1960s with varying fortunes. From 1949 to 1976, Maoist ideology imposed itself as the alternative to an indigenous and traditional moral code. But the demise of Maoism in the late 1970s unveiled a moral abyss that threatened to swallow the nation. The promises of the Four Modernizations, the adoption of repressive social control strategies to contain crime and spiritual pollution, and the formulation of twenty-first-century political agendas such as Harmonious Society and the China Dream have done very little to fill this moral void, or to offer a credible explanation for the idea of justice in modern China.

With this underlay of historical antecedents, how are dominant notions of justice conceived and sustained in China today? Here, we are not seeking to address a philosophical issue. The main question pursued in this book is not what constitutes justice in relation to contemporary Chinese moral philosophy or political philosophy strictu sensu, but how certain ideas about justice have come to be dominant in Chinese society and rendered more powerful and legitimate than others. This focus on the interrogative 'how' also incorporates a second and equally important question about how even the most powerful political ideas about justice can be challenged in an environment that does not favour, indeed actively rejects, political pluralism. In short, our aim in this book is to investigate the processes and frameworks through which certain ideas about justice have come to the political and social forefront in China today, and to explain how these ideas are articulated through spoken performances and written expressions.

Justice, like 'rule of law' and 'human rights', is a complex concept to analyse in any system. In examining China's legal system, such analysis is complicated further by the way scholars outside China choose, mindfully or unwittingly, to perceive the relationship between justice and state power. Over the last three decades, in subtle and sometimes unconscious ways, observers of Chinese law who are grounded in Western legal understandings have tended to limit how they conceive and therefore discuss law and justice in China.

When examining civil, administrative or criminal justice in China, observers from Western contexts who have such liberal understandings are often inclined to perceive these systems in terms 
of what they construe these systems are not (i.e., not a liberal system), using their familiar liberal concepts for analysis. Approaching justice as an object of study therefore involves a set of potential perception-based traps and snags that need to be avoided if we are to better understand the machinations of justice in China. We may inadvertently limit analysis of civil, administrative or criminal justice to questions shaped around an idealised notion of rule of law. Or for analysis we may adopt various rule of law models that can range from thin rule of law (Peerenboom 2002) to Weberian conceptions of rational institutionalisation. Or we may focus on law or justice via reference to themes such as human rights or Communist Party interference in the legal system. Whether analysis is informed by liberal values or focuses on models of rule of law for better or worse, the broader political spectrum is often obscured, and so too is the picture of justice presented.

These approaches tend to explain the hand of politics in the realm of Chinese justice in terms of a developmental trajectory that reduces justice operations to, or explains them away as, the outcome of the progression towards or retreat from some mode of rule of law (socialist or thin); as either 'advancement' of law (towards a thin 'rule of law') or temporary 'regression' into politics (a return to dominant Party politics and communist ideology). Such foci can inadvertently conceal key elements and political dynamics at work in the justice system as a whole, and can miss the wider political picture. An alternative approach is to see politics not as 'interfering' more or less in the justice system, but encompassing a range of social relations and processes much wider than liberal understandings usually perceive, including, but not restricted to, issues relating to Party dominance of the system.

A second and related tendency is to ignore the processes through which legal institutions develop their legitimacy and sustain their authority in a way that enables them to make certain claims about what is 'just'. This tendency was explored three decades ago, for instance, by John Brigham, in his influential study of the development of the authority of the Supreme Court in the United States, titled The Cult of the Court. He critiqued the conventional history of the Supreme Court, which relied on political explanations as the basis of its authority. This conventional understanding of authority assumed a polarity between law and politics. It assumed that authority was something that is 'given' or bestowed on the Court rather than something that is constantly in a process of being constituted and sustained (Brigham 1987).

Brigham's alternative was to place social action - the actions of social actors including judges and lawyers, appellants and so forth - at the centre of the Court's capacity to build authority. This approach saw the deeds and doings of social actors as central to how the Court continues to develop and sustain its authority: "Because institutions give action authority", he argued, it is necessary for researchers to think about how authority works, that is, how authority is developed and constituted through practice, rather than merely 'given' (Brigham 1987: 3). For him, the authoritative significance of the Court revolves around the tight connection between institutional practices and the discourses and the ideological frameworks of action that constitute the court as a legitimate political institution (Brigham 1987: 3). The practices of the Court are forms of social action that develop authority through the significance they are accorded in the community in which they operate (Brigham 1987: 24).

Brigham's work is based on the idea of law as an ideological and constitutive phenomenon, which has been one of the most influential concepts in the general field of socio-cultural studies in the last three decades. This idea comes from a tradition of socio-legal studies that prioritises the interrogative 'how'. Stuart Henry's work similarly illustrates the trend away from conventional realist and structuralist approaches to law that began in the 1980s in socio-legal studies. In his book Private Justice, Henry (1983) questioned conventional structuralist models of law as sufficient explanatory devices, arguing that such models of law created by structuralist theorising fail to capture the relationship between structure and agency that is crucial to understanding the operation and development of law and justice. He maintained that in attempting to achieve a 
comprehensive understanding of law, many studies failed to adequately explain the ideological process whereby 'some forms of law are rendered dominant while others are suppressed' (Henry 1983: 30). Henry suggested that conventional sociological analyses, while stressing the political and social structures that support particular forms of law, fail to explain the processes through which law is created as an 'object-like entity' (Henry 1983: 42): '[T]he crucial issue is not to seek an explanation which takes for granted the objective reality of the products of action and belief, but to delve beneath the paraphernalia of doings to expose the process of its construction and reconstruction' (Henry 1983: 24).

To trace the processes through which law is created as an object-like reality, Henry suggested we need to look into the ways that people interact with each other, since these 'construct and reconstruct the manifest appearance of law' (Henry 1983: 68). In short, rather than envisaging law as a series of ideal types or analytical models, Henry urged that we give precedence to studying the processes and mechanisms through which representations of law and justice are socially constructed.

In applying these observations to China, we come to see that there are limitations to studies that focus on rights and injustices through a subjective conceptual prism of what 'ought to exist' (i.e., for many western scholars, a liberal state rather than an authoritarian state). That kind of understanding can fail fully to appreciate how certain political ideas endure and indeed the role of the researcher in creating knowledge and cultivating understandings that contribute to this endurance. An alternative approach is to look at how justice-related practices (trials, civil mediation programs, policing operations and so forth) help to articulate a version of justice that upholds and strengthens Communist party-state power. It is important to understand how these practices 'construct and reconstruct the manifest appearance' of justice since these practices are precisely the key means of building and sustaining the party-state's politico-legal authority.

The studies presented in this volume explore the mechanisms that enable and sustain certain systems of justice or rule of law. The authors maintain that in a way similar to Henry's analytical approach introduced above, the processes and mechanisms through which discourses and ideologies about justice in China are constructed as an object-like reality require critical appraisal. As observers, we need to critically appreciate the public construction and reconstruction of these discourses and ideologies through the concrete judicial practices, policies and rhetoric. The chapters of this volume therefore seek to understand and explain the practices and processes that have come to dominate the polity in China since these have created political space for state actors to promote certain notions of justice and to claim these as representing dominant societal or socialist values. Justice operations and processes are conduits through which the party-state animates certain attributes that it attaches to particular notions of justice in ways that enable authorities to claim that these notions reflect the dominant social attributes of justice. Such practices sustain the dominance of, or even extend, the pre-determined notions of justice, while suppressing or rendering obsolete other counterposing notions. Here we see that far from an abstract concept, justice is at heart the product of a deliberate process that derives legal, political and social significance through social action. It is expressed through particular legal, social and political structures and processes that constitute, validate and sustain the power of some individuals or groups while limiting the power of others.

Because they ask 'how', the authors in this volume focus on the words and actions used to sustain the rationales of governance that drive the justice system in China today. Overall, in focusing on the performance of justice we are attempting to shift the analytical spotlight to the mechanisms through which certain notions of justice have been rendered legitimate or dominant in China and how others have been or are being suppressed or dismissed. The studies in this volume are informed by a variety of scholarly traditions, and only some self-consciously take up the constitutive approach to law and justice described briefly above. But while they may view the performance of justice in 
different ways and observe different performances of justice, these studies share a particular 'attitude'. They acknowledge text, language, spectacle and performance as crucial to how justice is understood and practiced in China. Some of the studies here focus on language and performance expressing the political and legal values that constitute the party-state sponsored glue that binds the Chinese justice system. The legal text is one place where the state's vision of justice is articulated and propagated. Spectacles of protest, punishment and retribution are some of the most poignant performances of sometimes incommensurate visions of justice. Other studies examine the language and performance of justice that helps to promote contesting values articulated by people who challenge prevailing party-state orthodoxy or party-state decisions that they claim are unjust. More often than not, these contesting views are expressed partly in language with origins in what is now seen as China's traditional value system.

Beyond their authors' shared attitude, the studies in this volume to some extent also reflect two main assumptions the book's editors share about how justice is communicated and performed through word and deed, assumptions that in many respects are novel to the field. Below we outline these two main assumptions that underpin the studies in this volume. One is that justice practices are not only instrumental but also performative. The other is that certain politico-legal discourses operating in China frame how justice is articulated by both the party-state and the people who challenge what is expressed as the dominant party-state worldview.

\section{The Instrumental and Performative Nature of Justice}

Operations and processes to administer justice in China are highly instrumental or utilitarian in both nature and purpose. To ensure the party-state achieves its desired outcomes, the instrumentalist/utilitarian concept of justice that it sponsors pervades every dimension of the PRC legal system. Activities such as law-making, law-enforcement, and adjudication and sentencing are the three most obvious dimensions of the PRC legal system, but another dimension that is extremely important is not easily visible. It is the dynamics within and across these three dimensions that the wider socio-legal field calls expressive or performative justice. This is where and how all-inherent politico-legal concepts, not just the concept of justice, embed solidly in all other areas of the legal system.

Justice practices and operations perform an expressive function that can - and usually do shape social attitudes and acceptance of certain political or social agendas. With this recognition, the idea of expressive justice has been studied in the fields of law and criminology outside China for decades. Yet little has been written about the utility of this conception for exploring Chinese justice. Socio-legal and justice scholars focusing on western jurisdictions have long argued that legal and judicial institutions create and sustain images of power and authority through the dissemination of ideas and principles that they announce and perform in routine everyday practice. In the criminal justice field, for instance, leading scholars have long recognised the expressive capacity of justice practices as conduits that organise, classify, and construct images and messages about law and authority. David Garland, for instance, argued more than two decades ago that the penal system 'acts as a regulatory social mechanism in two distinct respects: it regulates conduct through the physical medium of social action, but it also regulates meaning, thought, attitude-and hence conduct-through the rather different medium of signification' (Garland 1991: 194-5). Studies in the field of law such as Sarat and Kearns (1993) and Ericson (1996) also argue that law and justice practices have both a routine utilitarian role and a performative role. These practices are at once instrumental and expressive; while they function to secure the overall utilitarian objectives of maintaining social order and regulating social relations in a society, they also perform an expressive function because they operate as mechanisms that shape understandings and values at the popular level (Trevaskes 2003; 2004). With this recognition, the idea of expressive justice has been studied in the fields of law and criminology outside China for decades. Yet little has been written about the 
utility of this conception for exploring Chinese justice. As the authors in this book identify, the expressive dimension of law and justice practices pervade the entire Chinese legal system. Performance of these practices in settings where decisions are made transports justice from the realm of legal concepts to the cogs and wheels of the legal system, and through symbolism, to popular understanding beyond. Juridical performances are the pillars that sustain the politico-legal (zhengfa $\square \square$ ) culture of the PRC. They not only serve as the cement that binds law with politics, they literally enact, manifest and convey justice, enabling it to be visible to and ultimately accepted by Chinese society.

But it is not only party-state functionaries who perform justice. Those who challenge the party-state's claims to dominance over creation and maintenance of concepts of justice are also performers here through their social action. Some engage in the performance of justice through scholarly argument or social media commentary. Others engage in public protest, usually collectively pursuing in public what they perceive is lacking in Chinese society or is owed to them by society or state. People who protest against what they perceive to be injustice often draw from traditional ideas and concepts such as petitioning and other actions to demand that injustice is ceased and remedied. They reference traditional Chinese notions of 'injustice' (yuan 冤) that are well-known across Chinese society. Performing acts that draw attention to yuan is a way to increase the cogency or legitimacy of their protests. Images of protestors kneeling and begging for justice, or carrying placards adorned with the Chinese character yuan are obvious examples.

\section{Discursive Frameworks of Justice}

Since 1979, the party-state has advanced the goals of raising the people out of poverty; building a more inclusive society; achieving social harmony, sustainable economic growth and national development centred on the person; as well as achieving and maintaining regional and global hegemony. Each of these goals has been articulated and popularised through a corresponding political programme ranging from late twentieth-century agendas such as the 'Four Modernizations' and Deng Xiaoping's 'Rule of Law', to early twenty-first-century agendas such as 'Harmonious Society', 'Stability Maintenance' and the 'China Dream', and Xi Jinping's more recent 'Rule of Law' agenda. These agendas may differ in focus, but a singular 'red' thread underlies them all: the idea that individuals, society and the nation ought to be given what they are due. The thread is 'red' because the party-state is recognised as responsible for arranging this giving.

At different points in the history of the PRC, 'what they are due' has been variously understood in relation to what the Chinese polity and society has lacked: material security, political representation, an unpolluted environment or the respect of other nations. In this context justice is expressed at its most basic level, as a way of giving to each what they are due or giving to each what they deserve. This notion holds not only in Chinese tradition but also in ancient and modern Western thought. Its silence on agency - who/what should identify what/how much is due or deserved - is highly problematic and politically convenient. In China, as a minimum common denominator, this notion lies at the heart of party-state policy agendas, slogans and buzz-words. The party-state uses the popular understanding of 'what is due' in articulating its role as provider of justice and protector of society from injustice and inequality in order to give the populace what is perceived as their due. It has sought to fulfil its protective role by striving for the goals of raising the people out of poverty; building a more inclusive society; achieving social harmony, a sustainable economic growth; and a development centred on the people, achieving and maintaining regional and global hegemony.

The party-state also has other roles in the enactment of 'what is due', beyond providing what (it considers) is due to the people. It is instrumental in identifying and determining this 'due' for the people and in both determining and seeking to obtain its own due. What is determined as the partystate's own due - what its leaders identify as party-state prerogative - is the authority to define the scope and means to effectively realise its protective role over society and to create its own 
narratives to justify the choices it makes in performing this role. For instance, Article 33 of China's Constitution sets out the principle of mutuality of rights and duties, which inscribes the inseparability of the people's rights from their duties prescribed by the Constitution and other laws. As a condition of bestowing rights to citizens, the party-state is due certain duties and obligations from citizens. In this political logic, the party-state is due the right to govern in a socially stable environment. It can therefore justify withholding the rights of people, such as their freedom of expression, when they do not give the party-state its due. That is, the party-state has the faculty to bestow rights on citizens in the first place. The rights around leading a good life are promised by the party-state, and the ability to keep to this promise forms the basis of political legitimacy. The ability to bestow rights entails the possibility to withdraw the rights of citizens when they do not provide the state a socially stable environment in which to govern, such as by creating social disorder or failing to respect the authority of the party-state to dictate who is due what in society. The granting of civil and political rights was never part of the party-state's promise, therefore any accommodation made to allow individuals to express their voice should not be considered as an exercise of their rights, but as an indulgence.

The party-state dominates and jealously guards the political space around which this dominant political logic about justice is based. One way that it does so is by establishing and supporting certain notions of justice through discursive frameworks that help to shape and sustain particular political and legal values. Discourses are an enabling device, giving capacity for state functionaries to govern and respond to economic and social change in different ways for different purposes: from responding to threats to state and society, to providing legal frameworks for political oversight of power. Across the three decades of post-Mao China, the rise and fall of key justice operations and processes ranging through diverse practices from anti-crime campaigns to civil mediation have been maintained by legitimating discourses based on political agendas that have their foundations in a number of philosophical traditions, the most dominant being socialism.

Institutions involved in administering justice articulate their roles and responsibilities through key narratives that rationalise political choices in terms of not only the party-state's protective role over society but also what individuals within society deserve as their due. The partystate's current leading criminal justice discourse exemplifies this well. 'Balancing Leniency and Severity' (kuanyan xiangji 宽严相济) was introduced into the prevailing Harmonious Society discourse in the mid-2000s and remains dominant today in the Xi Jinping period. It has since been elevated to the status of China's leading and 'foundational' criminal justice policy. Balancing Leniency and Severity encompasses a myriad of criminal justice practice and nowadays is even a practising discourse in prison organisation (Nesossi \& Trevaskes 2016). Its premise is: 'When leniency is due, let leniency be given; when severity is called for, let severity be used' (当宽则宽该 严则严). This is a commonplace saying with origins in the classics and in imperial codes (Farmer 1995). The saying recurs in legal documents enacted throughout the last six decades, albeit until recently, under the rhetorical auspices of the policy of 'Combining Punishment and Leniency' (Leng and Chiu 1985: 129). This is also the meaning coded in contemporary political speeches by Xi Jinping (Legal Daily 2014). We see that the opening of this saying reaches straight for the familiar legitimising concept of 'what is due' (here latched to the notion of leniency).

Entire political programmes in China seek to legitimise the understanding that the partystate has the authority to determine who in society is to be given their due, what is owed to each person, and how what is owed to them differs according to an individual's status, conduct and other variables. For instance, the Stability Maintenance programme in the Hu Jintao era had as its underlying logic the idea that members of society have an obligation to the state to behave in ways that do not create social instability. Citizens 'owe' the party-state this due since the party-state needs a high degree of stability to successfully fulfil its protective role over society and provide a basis for the success of economic reform and development. Discursive frameworks like Stability 
Maintenance, especially those that seek to legitimise state-sponsored justice practices, enable authorities to rationalise the choices functionaries make about law and order. We see this in the policing practices of the Stability Maintenance period in the Hu Jintao era and in Xi Jinping's partyled rule of law today (Biddulph 2015; Trevaskes et al. 2014).

These frameworks derive their vocabulary from socialist ideology as well as from areas outside the discursive boundaries of socialism. It is not controversial to suggest that the legitimacy of the PRC and its legal system today rest largely upon the success of the nation's economic marketisation programme. Therefore, the language of the market is a crucial legitimising tool for state actions across the full spectrum of governance including the organs of justice administration. For instance, studies such as Michael Dutton's (2005) work on policing and contractualisation point to the prevalence of mangerialism in the contemporary policing lexicon in the 1990s and early 2000s. More recently, marketisation trends have induced an even stronger emphasis on social management. The party-state, not unlike other state entities, has favoured adopting key performance indicators in justice administration, which portray a notion of justice administration as a product of bureaucratic efficiency.

\section{Discourses of Justice in this Book}

In the $\mathrm{Hu}$ Jintao era, justice was administered via reference to performance indicators and repression in the name of Stability Maintenance, while in the Xi Jinping era it has been administered via reference to national security threats. These differences in approach to the administration of justice are, however, more apparent than real. At the core of both techniques of justice administration lies the two-fold claim that justice is a product of a strong state, and that a strong state represents a 'unity of interests' among different social and political actors. As powerful as it may be, this claim is vulnerable, as Joshua Rosenzweig (chapter 2) explains. In the face of economic and social polarisation, the party-state's claims about justice as a value created by a strong state, and the unity of interests among the people begins to break down, and a crisis of confidence unfolds. Joshua Rosenzweig traces such a crisis, observing the strategies the party had adopted to address it. His main finding is that Xi Jinping has been dominating discourse over popular justice employing numerous references to Maoism, using a strategy that is a mixture of propaganda, reform and repression.

While Maoism has gained renewed popularity in party discourse, much of the more general language of justice today remains embedded in the political philosophies of Confucianism and Legalism. An articulation of the idea of justice provided in the formulation of Balancing Leniency and Severity mentioned above is but one of many discourses dominant in the political arena today that have direct reference to past populist and statist notions of justice. As Delia Lin explains in chapter 3 on Confucian ideas about justice and their resonance today, the vocabulary, or rather, the veritable babel, of existing formulations of the term 'justice' includes words as diverse as yi (义), buyi (不义), zhengyi (正义), gongyi (公义), gong (公), gongzheng (公正), yuan ( $\square$ ) and qu (屈). While they refer to the same basic moral intuition, they are bearers of widely different philosophical and political meanings. These mostly ancient notions of justice continue to have impact in Chinese society today. They can be employed and communicated in conjunction with political agendas such as Harmonious Society. But equally, they can represent a set of established values or principles that is promoted not by the party-state but by those in the community who are seeking to influence the decision-making of those in power.

Lin sees two distinct articulations of justice at play in Chinese political philosophy that are apparent in state and social narratives of Chinese justice today. The first she calls 'high justice' and the second, 'low justice'. They represent two separate constituencies. High justice focuses on moral cultivation of the elite which situates political legitimacy and justice in the moral supremacy of the 
ruler and is articulated as yi. Low justice, instead, is the demand for fair treatment. She argues that there is a clear dissonance between the two, explaining that the Confucian paradigm of yi represents high justice, that is, the moral supremacy of the ruler, while attainment or not, of 'low justice' is not something that is seen to impact on the political legitimacy or moral supremacy of the ruling class. Since low justice is more about the attainment of fairness and social justice, it does not directly challenge $y i$ 'unless it is articulated in terms of challenging the moral supremacy of the ruler' as Lin notes. The logic of Confucian philosophy which is grounded in the idea of legitimacy attached to high justice dominates assumptions about state legitimacy in China today. The dissonance between high and low justice enables the continued dominance of a framework of thought in China in which the ruling class continues to articulate its rule in terms of not only ruling the nation in accordance with the law (yifa zhiguo 依法治国) but also rule by morality (yide zhiguo $\square \square \square \square$ ). Here is the continuation of a political framework in which, Lin claims, 'morals are politicized and politics is moralized.' Yide zhiguo enables the party elite today 'to claim that their intolerance of contrary ideologies is what brings order and stability'.

Statist notions of yifa zhiguo and yide zhiguo dominate party-speak in China today, and to some extent, continue to frame the scholarly Chinese literature on justice. A wide range of contemporary legal theory is taken up with Chinese scholars writing on Chinese jurisprudence which has in turn helped to shape the ways people in society talk about justice. These scholars make choices about which justice-related narratives are most appropriate and desirable and which contribute to realisation of the party-state's protective role over society. Therefore Chinese scholars have a hand in either supporting or challenging dominant narratives. As we find in Samuli Seppänen's study (chapter 4), the Chinese scholarly literature is framed around certain key legal narratives that make the possibility of embracing a liberal conception of justice limited, at least in mainstream Chinese jurisprudence. Under the understanding of justice promoted by the party-state, justice is not merely a moral intuition, but a value whose meaning ought to be consistent with its development goals and which the law should fulfil. A utilitarian notion of justice, one resting on a thick conception of the common good, is therefore sponsored by the party-state and has remained a dominant narrative in the literature. Given this state of affairs, it is all too natural that liberal (or thin) notions of justice, such as the one advanced by John Rawls, is rejected. Although there are indeed Chinese legal scholars who hold a thin conception of the good, in the marketplace of ideas in China, the Rawlsian conception of justice has been more or less ignored in favour of systems of thought that originated in the very heart of Continental Europe (Sapio 2015).

Actors in criminal trials also communicate and enact party-state discourses for the furtherance of party rule. This is true for discourses such as Balancing Leniency and Severity and for narratives built around 'miscarriages of justice' (yuanjia cuo'an 冤假错案). In chapters 5 and 6 respectively, Susan Trevaskes and Elisa Nesossi explore these processes in two distinct areas. Trevaskes examines the current Xi Jinping leadership's central political platform of 'Governing the Nation in Accord with the Law' (yifa zhiguo). She does so by surveying the medium and message of rule-of-law propaganda work (fazhi xuanchuan gongzuo 法治宣传工作) in the justice system in China today. She finds that the key propaganda message of yifa zhiguo today is the idea that ruleof-law and rule-of-party are essentially one and the same. Her examination also leads her to conclude that the politics-justice relationship in China is symbiotic. The party-state's political platforms present a discursive framework to articulate and justify justice system policies and responses to certain social problems. In turn, justice system functionaries help to positively advance political platforms through propaganda activities. Moreover, she finds that propaganda is a signaling device. The tone of the language from of propaganda issued from central authorities to the provinces, communicates the degree of intensity which the Xi leadership expects local authorities to respond to the party-state's core threats: corruption, crime and dissent. Finally, she also finds that to much greater extent than in Deng and Jiang's time, the Xi leadership stresses the utmost 
importance of centralised party rule over all aspects of government. And to advance this stance, the Xi leadership has emphasised the socialist claim about the harmony of interests between the people and the party that exists to represent them. This yifa zhiguo propaganda works to shuts down any alternative rule-of-law debate and any public discourse that calls for alternative ways to 'protect the people' other than through party rule.

Nesossi presents the case for the ways a certain notion of (state-sponsored) justice developed through the discourse on miscarriages of justice in twenty-first-century China. This process emerged through the public disclosure of some key events and trials throughout the 2000s and exposed wrongful convictions and a betrayal of justice. Those who revealed these injustices work within the very same authoritarian system as those who brought about the miscarriage of justice in the first place. Public discussion of wrongful convictions is often initiated and guided by criminal law experts, procuratorates and public security organs. Consciously or not, they articulate a political line that upholds the idea of the party-state's protective role in preventing injustices. While largely motivated by a political will to sustain political authority over the justice system, the role of party-state functionaries in pushing to redress injustices has had a perhaps unintended positive flow-on effect. The party-state still dominates political space around which the political logic of miscarriages of justice is discussed. Nevertheless, in recent years it has opened up the space for alternative ideas about justice to be discussed and argued. Opening up this space has enabled 'conversations' between citizens and functionaries. Getting justice redressed - getting what is due - is one of the outcomes of such conversations because it is in these conversations and through such debates in the press and social media that alternative conceptions of justice emerge.

The drama of the criminal trial can also be articulated in ways that further party-state political agendas. But the trial is also susceptible to being communicated in ways that challenge these agendas. As Flora Sapio explains in chapter 7, it is not inevitable that these alternative formulations of justice diverge significantly from official formulations. As a value that is created and put into practice by the public, justice is often equated with vengeance and conceived of in utilitarian terms. Sapio teases out both official and popular notions of justice by analysing the narrative woven around the Wu Ying case. This case involved a 26-year-old beautician who allegedly set up and ran an investment scheme involving party and state officials; the trial and conviction of Wu Ying could arouse intense feelings of (in)justice among the public. Popular feelings of justice, as they were articulated and expressed in public and social media commentaries, however did not coalesce into an alternative to the moral code held by the judiciary. On the contrary, both the public and the judiciary articulate justice as a value which is indigenous and not universal. The conception of justice that they hold is furthermore compatible, and at odds with the conception of justice advocated for by the 'third realm' described by Rosenzweig (discussed below). State-sponsored and popular claims to moral diversity are leading to a dilution, rejection or revisitation of all those moral and legal values seen as not belonging to the Chinese tradition, including those held by the rights defence movement.

Since the Chinese politico-legal system is monopolised by a single party, it is often thought to be inhospitable to influences that do not emanate from within the party-state itself. The monopoly of power is perceived to run hand in hand with a monopoly on information, on ideology and on opinion. Yet what has developed over the last 15 years or more years is the emergence of what Rosenzweig calls a 'third realm' which is situated between the private realm and the state. This third realm is made up of multiple publics, encompassing the rights defence movement, bloggers and others who find outlets for protest or contestation. While certainly not an organised force capable of challenging party power, this third realm has nevertheless found a powerful voice by banding together ideas around key events such as criminal trials or outrageous examples of injustice that capture the public's attention and challenge dominant party narratives. As Ira Belkin discusses in chapter 8 , public opinion can have a concrete influence on the outcome of individual 
criminal cases, becoming instrumental in determining when one defendant ought to be treated leniently and another ought to be treated severely. The influence of public opinion on individual criminal cases provides one of the best illustrations of how justice can be delivered by the people, in ways not dissimilar to the popular justice of the Mao era. While the site where the public performs justice has shifted from the physical space of Maoist mass rally sites to the virtual space of the Internet, there has been remarkable continuity in the dynamic. Such continuity of public mass rallies in person or electronically complicates reform in a justice system that places such a high premium on social stability. Strong public opinion in a particular trial or in relation to a perceived injustice does not always result in redress. The high premium on stability can frustrate attempts by both the public and the central authorities in Beijing to remedy injustices and to curtail the arbitrary and abusive use of adjudication powers by local judges. Any attempts to achieve a greater measure of judicial professionalism and consistency across the justice system nationwide necessarily require renegotiation of power relations at the local level of the justice system.

Dominant statist concepts of justice are, of course, not immutable. They are informed by political and historical contingencies. Such pliability is a double-edged sword which allows the partystate to alter with relative ease the meanings of justice in accordance with the party-state's perception of current socio-political needs. But allowing the involvement of public opinion in shaping ideas of justice or redressing injustice denies the party-state an unchallengeable monopoly on this concept. Because the concept of justice can be discussed by the public, defined and redefined in ways which influence concrete practices, certain discursive spaces that were once the sole monopoly of the party-state can be opened up and dominant views contested. Cultural ferment in some sectors of society has coalesced into an alternative rights-centred movement that sees justice as 'giving to each what they are due' in terms of both substance (substantive justice) and process (procedural justice). Their demand for due process is meant to be a constraint upon the pursuit of the party-state's utilitarian goals.

Chinese citizens have maintained an ability to adopt an alternative vocabulary, rooted in Chinese tradition, to articulate notions of justice that are incompatible with the state-centre values of justice. Pils (chapter 9) conceives of justice as an interpretive concept, a concept that possesses a fluidity that becomes visible as soon as the observer chooses to understand the concept of justice through the set of values related to it. She provides an excellent example of such fluidity through an analysis of the concept of yuan (冤) and the concept of rights. A word drawn from the vocabulary of classical Chinese, yuan stands for 'moral wrong', 'tort' or 'injustice', and conveys a different conception of justice, inspired and driven by the goal to implement a strategy of political resistance to state repression. Yuan is part of a moral counter-tradition related to a cosmology and metaphysics which see human actions and the broader natural order of the cosmos as being two different parts of the same unity, enmeshed in a process of mutual action and reaction. Unjust actions disrupt the natural order, and the responsibility for restoring the order of nature and punishing its disrupters, lies with the wronged. The concept of yuan, Eva Pils argues, entails an important element of moral agency. Moral agency in turn, is closely linked to a moral philosophy that sees rights as attributes of the individual, rather than as belonging to the collectivity. Inconsistencies and tensions may exist in the various ways in which the ideas of yuan and individual rights are expressed, staged and performed in public discourse, in complaints and petitions. However, these seeming contradictions are inherent in the process where an alternative moral code is created, adopted and advocated by Chinese citizens involved in political and human rights advocacy. While this alternative moral code has not been recognised by the party-state to date, such a lack of recognition has not yet affected how those who identify themselves with the community of the wronged, the yuanmin, conceive their plight. The moral tradition that revolves around the concept of yuan provides a response to party-state dominant conceptions of justice. Despite its internal tensions, it is a moral tradition that could provide a bridge between Chinese 
conceptions of justice, and those elaborated by Western moral philosophy.

Acts that disrupt social stability can puncture the political perimeters around official notions of justice that the party-state guards. Behaviours such as public suicides have the clear goal of disrupting social tranquillity and to draw attention to injustices. The increasing frequency of this conduct among the pool of the 149 million Chinese migrant workers in the first decade of the twenty-first-century is a significant signal in itself. In chapter 10, He Xin, Wang Lungang and Yang Su shed light on this spectacular of injustice in their analysis of why migrants choose to employ disruptive tactics. They find that the power of protest that uses the notion of yuan generates an alternative notion of justice among migrants and other disadvantaged groups to that presented in official discourse. This alternative notion of justice, embedded as it is in Chinese traditional culture, motivates them to undertake disruptive actions. In contrast to the groups examined by Eva Pils, the workers analysed by He, Wang and Yang do not situate themselves as antagonists to the party-state and the legal system. Their consciousness of having been treated unjustly, as in the cases of delayed wage payments, is not related to their consciousness of the law and the legal system. Their demands for a fair and prompt compensation for their work are instead seen as arising from a broader sphere of 'natural' justice that transcends the narrower domain of the law. He, Wang and Yang also find that legal reform that responds to these protests often ends up creating further exclusion and division. This outcome can be explained, as they do, with the fact that migrants' conceptions of justice do not take into account the demands of the legal system. The widespread use of disruptive tactics instead of formal channels of dispute resolution stems from the difficulties that migrants experience in relating their own ideas about justice and individual rights to the broader framework of the rights and duties created and imposed by the law. On their part, responses of governmental actors to these disruptive strategies create incentives to adopt disruptive protest tactics.

Politics and law intersect in all of the chapters mentioned thus far. A closer scrutiny of the politics-law nexus is given in the final section of the volume in chapters 11,12 and 13 respectively by Margaret Woo on civil law, Sarah Biddulph on administrative law and Hualing Fu on access to justice. Traditionally civil law has been considered one of the areas of the legal system where the nexus between law and politics is looser than elsewhere. This view of the role of civil law in the PRC legal system has been influenced by considerations about the role civil law ought to play - that of allowing individuals to appear as equals before a court of law either to solve their disputes, or to challenge those who are in power. Chinese civil law, however, appears to enshrine a different set of values, that privilege stability over notions of legal equality. Margaret Woo observes how the depoliticisation of civil law is only apparent, and not real. Beneath the technicalities, civil procedure rules embody a notion of justice that seeks to bolster the role of the state while at the same time appeasing citizens, giving to each what each is due. Subsumed under the broader ideological label of 'harmony', this goal has been reached through the establishment, in 2012, of a multi-track civil dispute resolution system. Under this system, the needs of the lower and less educated strata of the population are addressed through alternative dispute resolution mechanisms, while the state maintains significant control both of litigation proceedings and the courts in those cases which may potentially threaten social stability. The adoption of a multi-track dispute resolution system echoes the notions of 'low justice' and 'high justice' put forward by Delia Lin. If the notion of justice is not univocal but binary, if in 'giving to each what it is due' the 'what it is due' is determined by one's position relative to the party-state, then the existence of both procedural and substantive differences in the means used to dispense justice ought to be acknowledged as one of the defining features of the legal system.

Sarah Biddulph's chapter takes up the themes of performance and language as a way of exploring official concepts of justice in the legal treatment of sex workers and their clients. She analyses performance in the form of spectacles of humiliation of sex workers and language in the form of a detailed analysis of the legal texts that enable their punishment. She seeks to excavate a 
vision of justice that looks beyond rhetoric to that instantiated in the laws and rules and in enforcement practice. It reveals the coexistence of concepts and values that are in fundamental tension with each other. The chapter explores the concepts of justice along two axes. The first considers the degree of institutionalisation of the administration of justice in the supposed move from populist, mass-line forms of justice exemplified in the public parading and humiliation of sex workers, to a more institutionalised, bureaucratic form of justice bound by legal rules and procedures. The second axis considers the values of the text of the law and the ways it institutionalises power in the move from state-oriented governance to people-oriented governance. State-oriented governance favours legal authorisation of state power and the convenience of enforcement agencies, whereas people-oriented governance ostensibly embraces humanism and places greater emphasis on the interests, needs and rights of citizens. However, another meaning of people-oriented governance emerges - to align the administration of justice with the people's feelings - which does not necessarily correlate with protection of the individual's rights but harks back to populist modes of justice. Ultimately, the chapter concludes that populist forms of justice have not been displaced by formal legality but has instead been incorporated into formal legality, that people-centred governance has not displaced state-centred governance but that they coexist, and that each of these seemingly contradictory elements coexist. Of course, the corresponding incoherence of the rules and enforcement practice ensures that there is also a radical disconnect between official notions of justice and the experiences of person subject to sanctions.

In the West, the issue of access of justice tends to focus on the legal aspects of availability, accessibility and affordability in relation to court-centred legal services for those in society who are marginalised or vulnerable. In his chapter on access to justice in China, Hualing Fu explains that a primary focus on law and courts is typical of the field that sees issues of access as being primarily about how social and economic conflicts are converted into justiciable legal claims and given corresponding judicial remedies. Given this, the political nature of rule of law is a neglected feature in the scholarly and practitioner fields that concern the global promotion of rule of law. The emphasis, he argues, tends to be on the 'doorstep conditions' for the rule of law as defined by western-liberal thinking. This thinking sidelines the political use of law when applied in the developing world, regarding law as a technical governance tool rather than seeing it as dynamic and complex in its interaction with politics. When applied to the area of access to justice, this focus on law and courts, and not on the political atmosphere in which it operates, fails to capture the ideological and political foundations upon which concepts of justice are defined and redefined in practice by various social actors. To remedy this over-legalised assumption about access to justice, $\mathrm{Fu}$ explores the dominant features of access to justice and discusses the limits of that legalistic approach in the political context of China.

\section{Concluding Remarks}

This book is essentially about how different and competing narratives of justice are articulated and acted out in contemporary China and the various stages on which they are performed. Each chapter in this volume in different ways reflects the idea that language and performance are crucial to how justice is understood and practiced. This shared attitude gives us a wide lens to view the myriad structures and the processes through which justice is communicated and performed to its social audience in a wide range of justice practices: civil, criminal and administrative.

Party-state legitimacy in China today is articulated in terms of the moral supremacy of the party to represent the interests of the people and it rests on the assumption that it alone has the capacity to drive economic development and protect society from the social instability that might threaten wealth creation. The party-state puts to use a wide array of discourses to support its claims of legitimacy and the language of justice is central to these discursive claims. It claims the right to demand unity of thinking about how it governs and expresses this through the channels of criminal, 
administrative and civil justice.

But the idea of the expressive nature of law and justice extends well beyond the official criminal and civil justice system to encompass all aspects of the justice arena including aspects of expressive action that have their origins in civil society rather than in party-state practice. In the chapters that follow we find much evidence of this expressive role in the actions of party-state players, since justice practices are conducted in a much more self-consciously overt and politically oriented manner than is the case in western-liberal settings. Criminal and civil justice in China is something that is quite literally carried out, staged and performed in workaday social and political environments such as the courtroom, the police station, the prosecutor's office or detention facility. Both discourses and visible manifestations of trials and other judicial actions are related facets of expressive justice. It is through them that the idea of justice is communicated and enacted, leaping from the world of concepts to the actual world of the courtroom, office or street.

Functionaries working at the behest of the party-state are not the only actors who perform justice. People who challenge the party-state's political claims about what is or is not just are also performers through their social actions which include scholarly or media commentary and public protest. Expressing justice through rituals and counter-rituals, performances and counterperformances is a crucial part of putting into action alternative notions of justice. The claims of injustice made by those who have lost out on the promises of financial or social security or political representation do not depart far from traditionally held notions of yuan. Part of the movement amongst defence lawyers and others who seek yuan is the basic argument that like cases should be treated alike. Until very recently neither legal philosophies nor enforcement practices by the partystate have paid much attention to this idea of procedural justice as a discrete goal of justice administration in China. Recent reforms to coercive administrative powers have seen the introduction of politico-legal catchwords that nominally at least, require government and judicial organs to follow this basic principle of procedural justice in their day-to-day operations.

The introduction of principles of procedural justice and the political-legal catchwords that refer to procedural justice will involve processes of interpretation. These will result in the establishment of an orthodoxy of meaning, and in the progressive marginalisation, if not the weeding out, of interpretations that become labelled heterodox or heretical. If justice is a complex concept, one that is staged and performed by myriad social and political actors, then the choice of script and the selection of actors are perhaps what truly bring the idea of justice to life. 


\section{References}

Biddulph, S. 2015. The Stability Imperative: Human Rights and Law in China, Vancouver: UBC Press.

Brigham, J. 1987. The Cult of the Court, Philadelphia: Temple University Press.

Dutton, M. 2005. Policing Chinese Politics: A History, Durham NC: Duke University Press.

Ericson, R. V. 1996. Why law is like news. In David Nelken, ed., Law as Communication. Aldershot: Dartmouth, pp. $195-230$.

Farmer, E. L. 1995. Zhu Yuanzhang and Early Ming Legislation: The Reordering of Chinese Society Following the Era of Mongol Rule, Brill: Leiden, New York, Köln.

Garland, D. 1990. Punishment and Modern Society: A Study in Social Theory, Chicago: University of Chicago Press and Oxford University Press.

Garland, D. 1991. Punishment and culture: the symbolic dimensions of criminal justice. Studies in Law, Politics and Society, 11, 191-222.

Henry, S. 1983. Private Justice, London: Routledge and Kegan Paul.

Legal Daily. 2014. Yong Xi Jinping zongshuji zhongyao jianghua jingsheng tongyi sixiang zhidao shixiang tigao zhengfa lingdao ganbu nengli he zhengfa gongzuo zhengti shuiping (Use the spirit of the important speech of General Secretary Xi Jinping to unify ideology, guide practice, raise the professional capability of political-legal cadres and the overall level of political-legal work) Fazhi ribao, 23 April. Available from: www.legaldaily.com.cn/index_article/content/201404/23/content_5471583.htm?node=6148. Accessed on 10 May 2016.

Leng, S. C. \& Chiuh H. 1985. Criminal Justice in Post-Mao China: Analysis and Documents, Albany: State University of New York Press.

Nesossi, E. \& S.Trevaskes 2016. Framing imprisonment studies in china: ideology, law and politics. In E. Nesossi, S. Biddulph, F. Sapio and S. Trevaskes eds. Legal Reforms and Deprivation of Liberty in Contemporary China, UK: Routledge.

Sapio, F.2015. The 'four nevers', socialist core values, and 'western' values. Telos, 171 (3), 99- 106.

Peerenboom, R. 2002. China's Long March Towards Rule of Law, Cambridge: Cambridge University Press.

Sarat, A. \& Kearns, T. R. 1993. Law in Everyday Life, Ann Arbour: The University of Michigan Press.

Sarat, A. \& Kearns, T. R. 1998. Law in the Domains of Culture, Ann Arbour: The University of Michigan Press.

Trevaskes, S. 2003. Public sentencing rallies in china: the symbolizing of punishment and justice in a socialist state. Crime, Law and Social Change, 39: 359-82. 
Trevaskes, S. 2004. Propaganda work in chinese courts: public trials and sentencing rallies as sites of expressive punishment and public education in the People's Republic of China. Punishment and Society, 6 (1): 5-21.

Trevaskes, S., Nesossi, E., Biddulph, S. \& Sapio F. eds. 2014. The politics of law and stability in China, Edward Elgar: London. 


\section{University Library}

\section{- M M N E R VA A gateway to Melbourne's research publications}

Minerva Access is the Institutional Repository of The University of Melbourne

Author/s:

Sapio, F;Trevaskes, S;Biddulph, S;Nesossi, E

Title:

The Expression of Justice in China

Date:

2017

Citation:

Sapio, F., Trevaskes, S., Biddulph, S. \& Nesossi, E. (2017). The Expression of Justice in China. Sapio, F (Ed.). Trevaskes, S (Ed.). Biddulph, S (Ed.). Nesossi, E (Ed.). Justice: The China Experience, Justice: The China Experience, (1), pp.3-25. Cambridge University Press.

Persistent Link:

http://hdl.handle.net/11343/254296 